\title{
THE INFLUENCE OF ROMANIAN STUDENTS' CHOICES IN HIGHER EDUCATION ON EMPLOYMENT RATE AND JOB SATISFACTION
}

\author{
Alina Nicoleta DOBRE ${ }^{a *}$, Andreea BREAZU ${ }^{b}$, Simona Cătălina ȘTEFAN ${ }^{c}$ \\ ${ }^{a, b, c}$ Bucharest University of Economic Studies, Romania
}

\begin{abstract}
In recent years, the role of higher education has increased significantly in the development of national economies, due to the expansion of the knowledge economy, which creates and transforms knowledge into innovation. This paper aims to analyze elements of job satisfaction of people who have completed higher education. Thus, the study was dedicated only to graduates of a higher education cycle and to those who are active on the labor market. As anticipated, the research results revealed that the specialized knowledge influences the employment rate of the graduates. At the same time, the results also indicated that a high level of knowledge acquired during specialized studies (specialized knowledge, IT, teamwork, ability to analyze and synthesize, critical thinking) contributes to increasing employee satisfaction at work. The usefulness of this study lies in the fact that it helps young people in choosing the future field of activity, as they know that a job in the field of specialized studies contributes to increasing job satisfaction.
\end{abstract}

KEYWORDS: higher education; job satisfaction; knowledge; migration.

DOI: $10.24818 / \mathrm{IMC} / 2021 / 04.09$

\section{INTRODUCTION}

The emergence of the phenomenon of globalization and the introduction of technological progress had a strong impact on the economic, political and socio-cultural environment. They brought with them many opportunities, but also several challenges. It is well known that globalization has the benefit of creating jobs or developing existing ones, but this can also lead to the loss of jobs that no longer meet professional standards. A direct effect of globalization is increasing competitiveness. In this context, an important role is played by employees in the labor market who aim to maintain competitiveness in order to secure jobs. A vital element for competitiveness, as well as for the capacity for professional insertion, is represented by their skills, which must be as developed as possible and relevant for the labor market.

Lately, employers tend not to give due value to higher education, knowledge acquired in college, so you can see an increase in experience requirements at the time of recruitment. This topic has been debated in other papers, Drewery \& Pretti (2021) have focused on analyzing what are the relevant work experiences of students because they had a higher chance of employability. Thus, they interviewed a larger number of students, graduates from different fields to find out from their perspective what is the most important aspect when they manage to get a job. Most of them confirmed that the existence a "background" would really help in this hiring process, the participants feeling much more secure in a field they know.

We noticed that less research analyzed that there would be an influence in the educational choice of university education on the employment rate and job satisfaction. We consider that the relevance of

${ }^{*}$ Corresponding author. E-mail address: alina.dobre@man.ase.ro 
the proposed topic is important for the academic university environment, the people who are going to choose a field of study but also for the companies that are in the process of recruitment. Therefore, we have chosen to study this subject in more detail in order to bring value of the subject.

The purpose of the research is to determine the influence between the knowledge acquired after studying a field and the employment rate, as well as their influence on job satisfaction. Simultaneously with the main purpose of the paper, we also looked at secondary elements such as: the impact of internal or external migration, the employment rate of people who are active on the labor market in the same sector with graduated studies and statistical differences in terms of job satisfaction, between persons working in the field and persons who are employed in other fields of activity.

The study includes as a research method, the opinion poll, and the research tool used is the questionnaire, which is developed in three sections. As we wanted the analyzed answers to come from respondents who meet the research criteria, three filter questions were included at the beginning of the questionnaire, regarding the desire to participate in this research, the status of employee on the labor market and the level of studies completed. Subsequently, the persons who did not meet the criteria for participation in the research were removed from the database for a conclusive statistical analysis.

The paper is structured in four chapters, in the first part we present elements of literature that contributed significantly to the choice of study topic, then we presented elements of methodology continuing with the statistical results that confirmed or refuted the proposed hypotheses. In the last part of this paper, we can identify a series of conclusions and limits that formed the basis of this research.

\section{LITERATURE REVIEW}

At the level of the European Union (European Commission, 2020) it was found that there is a gap between the skills acquired in the education system and the skills required in the labor market. This justifies the need for skilled workers to increase productivity and ensure continuous innovation in a highly globalized economy.

To address concepts such as inclusion and social integration, it is necessary to ensure basic skills (reading, writing, arithmetic, science and technology), which provide access to the labor market and maintaining a stable and quality job. Recent changes in the economy require the possession of transversal skills, represented by those skills relevant to the practice of a profession acquired through education and training activities or through non-professional, recreational activities. These skills have been acquired in a context for solving a special problem and can be transferred to a context other than learning (European Commission, 2020).

The European Higher Education Area (EHEA), created by 48 countries for over 20 years, aims to implement the Bologna process. The report of this structure (Commission / EACEA / Eurydice, 2020) shows that most countries have seen an increase in the enrollment rate of students in higher education, $56.4 \%$ of whom are enrolled in the first cycle of studies. There has also been an increase in academic staff in more than half of the 40 countries for which data were available, as well as in higher education institutions, which may be due to the growth of the private university sector.

In a recent study (Robotă, 2018), academic performance is described as representing a student's level of knowledge being measured by grades. Thus, it was shown that low academic performance was identified in superficial students, who had a low desire for improvement, lacking the preference for further learning. Academic performance is also determined by the persistence of students in the academic training activity, which is lower in the case of students with a low level of perseverance and vice versa.

Employment is an activity related to meeting personal and social needs. Therefore, the employment rate of the population is determined by the ratio between the active labor market population in a given age group and the total population of the corresponding age group as a percentage. At the 
same time, it is necessary to keep in mind that full-time and part-time employees are considered equally.

As this research seeks elements that can influence the employment rate, we can see that in recent years, the role of higher education has brought significant to the development of national economies, this has been fostered by expanding the knowledge economy, which creates and transforms knowledge into innovation. The level of education is a major element of competitiveness in the labor market. Thus, as the level of education in a certain country increases and the category of the unemployed is significantly reduced (Matiuk \& Bessarabova, 2020).

There are several long-term benefits highlighted in the development of the level of education that can include both job creation, increased professionalism and competitiveness between individuals. These can be traced in a chain of events such as: increasing the level of education - increasing family income - increasing tax income - increasing savings and investments.

The research written by Şerban (2010) presents information on the share of people with higher education in 2010, therefore, a percentage of $23 \%$ of the population of our country manage to pursue specialized higher education. In the same year, only $12 \%$ of the total population aged 15-64 managed to complete a higher education program.

Making a comparative analysis with more recent information (Eurostat, 2021a), Figure 1 shows the situation of 2018-2019 in which our country is positioned. As a result, according to statistics, in 2018-2019 Romania had a share of only $18.2 \%$ of the total population aged 15-64. Compared to the European Union average (41\%) and according to the Bologna report (Education, Audiovisual and Culture Executive Agency, 2010), Romania is still on the last places in terms of the rate of people with higher education.

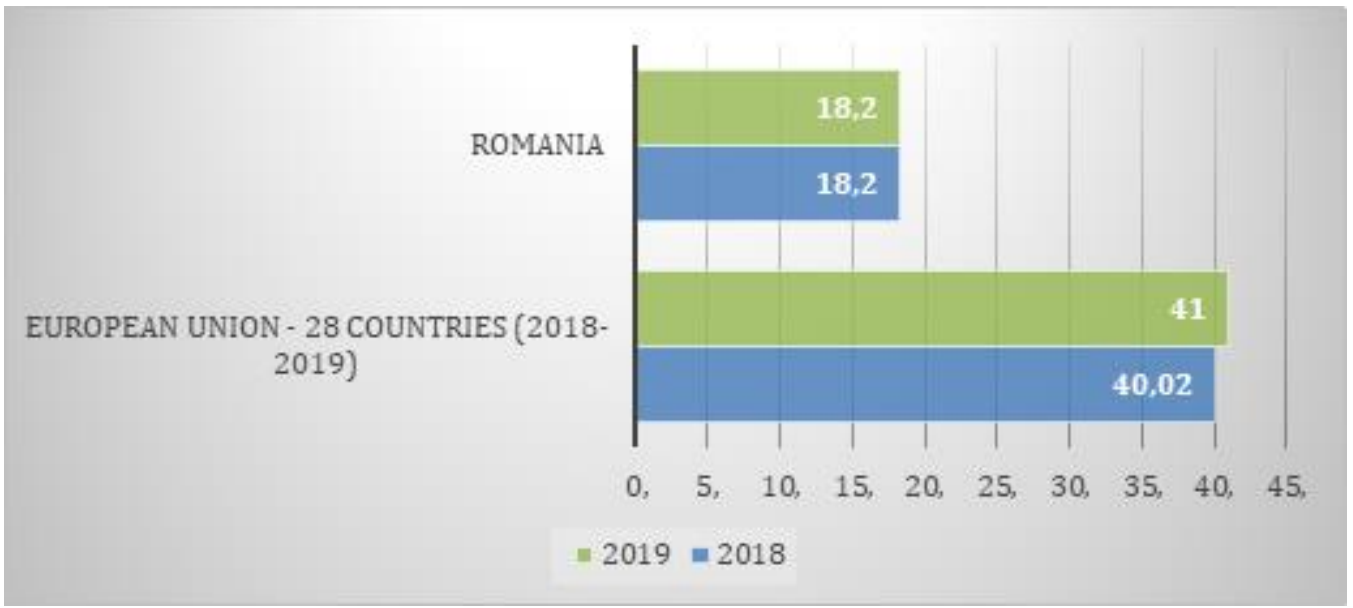

Figure 1. The Romanian Higher Education Level

Source: authors, using Eurostat Data (2021a)

Regarding the employment rate in Romania, according to Eurostat reports (2021b), this indicates a high share compared to the average of people with higher education. Thus, according to the information provided in Figure 2, it can be seen that the average of the European Union in 2020, the first semester, is $2 \mathrm{pp}$ higher compared to the Romanian average. The SARS-CoV-2 virus pandemic has affected the world economy but also employment, our country being directly affected in this sector of activity. However, the employment rate decreased until this year, the first semester, to 5 pp. 


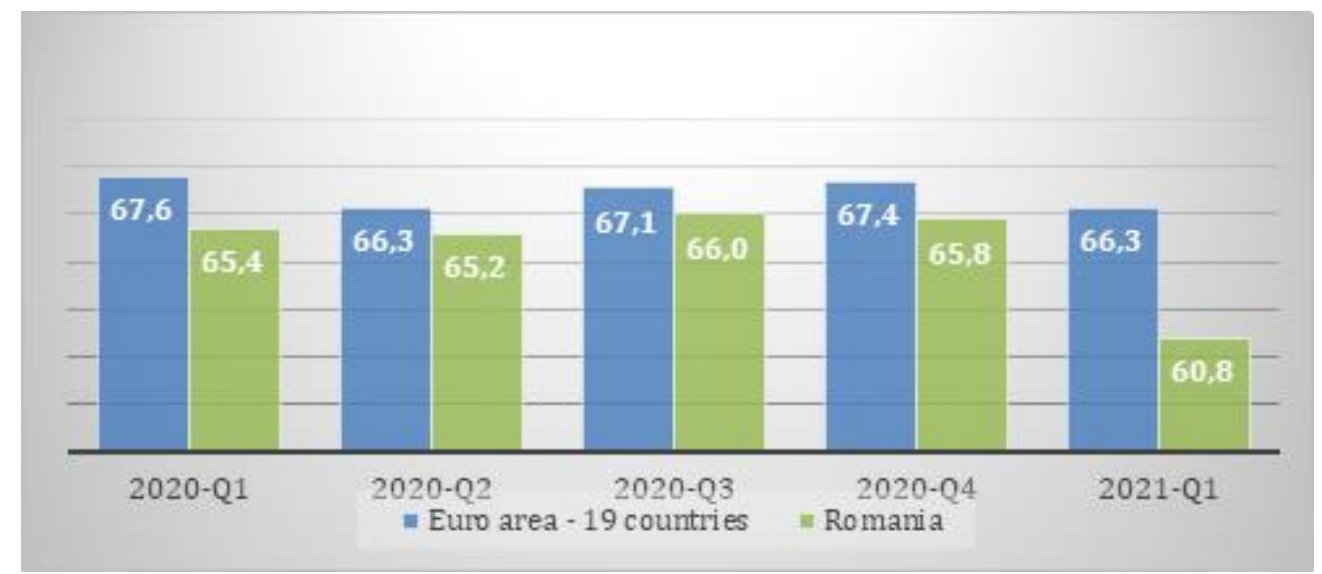

Figure 2. Romania's employment rate in the last 2 years compared to the EU Source: authors, using Eurostat Data (2021b).

All these highlighted aspects prompted us to outline a first question of our study, namely: Does the specialized knowledge have an influence on the employment rate of graduates and job satisfaction? This question determined us to outline the first hypothesis of our research:

\section{H1: Expertise has a positive influence on graduate employment rate and job satisfaction.}

Another notable phenomenon that has spread with globalization is migration, even though it has been present since the disintegration of medieval society and the development of the new industrial revolution, it has influenced the world in all sectors of activity.

There are several studies that debate the theory of migration, but none fully cover all the aspects that can cause a person or a society to migrate. The most mentioned factors are related to economics, sociology, demography and finally educational.

The academic environment has also been strongly influenced by migration and globalization. One of the pillars of the internationalization of higher education is the mobility of students, which seems to have growing international dimensions to date. The flow of students across borders is designed to bring them into a diverse context and therefore to form a rainbow of cultures and values (Chellia, 2018).

However, our research aims to analyze only a small niche of migration, internal and external migration of students and new graduates, respectively. Consequently, it is not a novelty that the persons with a bachelor's degree, in areas where employment has increased competitiveness, intend to leave the country to meet their financial needs, are numerous specialized studies. which states this theory, for example (Svabova, et al., 2019) mentions the fact that the main problem of a poorly developed country is the insufficient connection of the educational process with the needs of the labor market. Consequently, people who complete different fields of higher education identify the fact that the labor market cannot satisfy the basic, primary need. There are other elements that influence migration, if we refer to internal migration, we can mention that most people, even future students migrate to major cities - university centers in order to specialize and settle in a place with many opportunities of professional development.

Figure 3 shows the number of people leaving Romania in the main sectors of activity, after graduating, of course we chose to introduce in this presented and two neighboring countries, Hungary and Bulgaria to perform a comparative analysis. Therefore, from Romania in 2020, on average 2043 thousand people chose to leave the country, to work or develop professionally in another geographical region. If we analyze the averages of our neighboring countries, Hungary 
1562 thousand people and Bulgaria 985, we can see that Romania has become an exporter of qualified people in various fields (Eurostat, 2021c).

An unfortunate event is the fact that on average 1089 thousand people in the medical field decided last year to leave the country to work in other countries, where obviously the salary level is well above the average salary offered here. The figures also indicate that some people, working in the administrative field, respectively 500 thousand people have chosen this career path.

However, current research focuses on people who have recently completed a higher education cycle, Figure 3 showing the total number of specialized people.

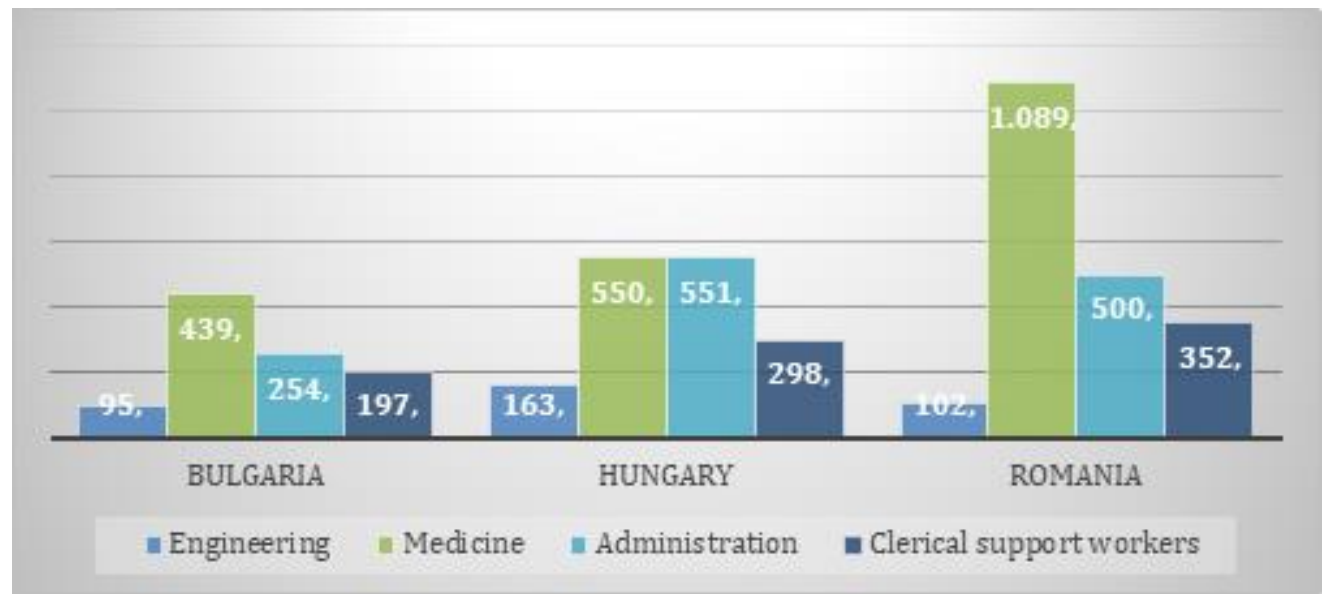

Figure 3. The average of people with higher education who emigrated in $\mathbf{2 0 2 0}$

Source: authors, using Eurostat Data (2021c)

Thus, all these aspects prompted us to outline another question of our study:

\section{H2: Internal and external migration has a positive influence on job satisfaction.}

Productivity plays a major role in any organization, so for the highest possible productivity, in theory and in practice, employees must be satisfied at work. There are many psychological studies conducted on job satisfaction, creativity, forms of motivation that have been done over time to see what elements, factors determine people to be productive and happy at work. the work. Positive evaluation of one's own work in an organization or positive experiences can be defined as elements of job satisfaction (Padmanabhan, 2021).

A psychological study conducted by some researchers in their work (Desselle, et al., 2018), presents a hypothesis according to which the average time spent at work directly affects employees. Therefore, a short time spent at work motivates employees to have greater satisfaction.

What happens to new graduates and what is their level of job satisfaction? Of course, in search of this answer there are a lot of factors that can determine different answers. As a result, according to Henry Maslow's theory mentioned in (Lefter, et al., 2008), each individual must satisfy both primary and higher needs, from physiological needs, to safety, to belonging to self-development. In the first professional stage, the graduates pursue elements of a financial nature, and with the passage of time they move towards the desire for self-development specialization.

Eyupoglu \& Saner (2009) investigated in his paper the relationship between age, occupational level and general job satisfaction depending on the professional level and specialization. As a result, people who have a graduated organizational commitment in the field of specialized studies are much more satisfied in terms of development opportunities. Also, in this study it was highlighted the fact that although from a financial point of view the respondents are not fully happy, which 
determines the individuals to work in other fields of activity than the graduated ones. This led us to develop another hypothesis of our study:

H3: There are statistically significant differences between the satisfaction of persons employed in the field of specialized studies and the satisfaction of persons employed in a field other than that of completed studies.

\section{RESEARCH METHODOLOGY}

The article is dedicated to the study of the relationship between educational choice in university education, employment rate and job satisfaction. The issue of internal and external migration was also considered, namely the migration of students from small towns to more developed cities, university centers and those with undergraduate studies completed or in the process of completion to other cities outside Romania.

The purpose of the research is to determine the influence between the knowledge acquired after studying a field and the employment rate, as well as their influence on job satisfaction.

In this context, the target group of the research consists of people who have completed their undergraduate studies and who are active in the labor market at the time of completing the questionnaire. Within the target group, 145 responses were collected, representing the sample in which the hypotheses of our research will be tested. Based on the literature (Boddy, 2016; Dell, et al., 2002; Krejcie \& Morgan, 1970) which provides various methods for determining the sample, we appreciated that, although the sample size is small, it can be considered representative as a result. of the distribution of graduates on different fields of study.

The study includes as a research method, the survey, and the research tool used is the questionnaire, created on the Google Forms platform. The questionnaire was distributed online to friends, colleagues, relatives through platforms such as WhatsApp, Microsoft Outlook, etc.

The structure of the questionnaire consists of three sections. As we wanted the analyzed answers to come from respondents who meet the research criteria, three filter questions were included at the beginning of the questionnaire, regarding the desire to participate in this research, the status of employee on the labor market and the level of studies completed. Subsequently, the persons who did not meet the criteria for participation in the research were removed from the database for a conclusive statistical analysis. The first part includes demographic questions that refer to gender, age, year of graduation and the field of undergraduate studies, pursuing a master's program, employment in the graduate field and seniority.

The following sections of the questionnaire are based on a Likert scale from 1 to 5 . In the case of all variables (employment rate, specialized knowledge, migration, job satisfaction) the same measurement scale from 1 to 5 was kept, where 1 represents to a very small measure and 5 represents to a very large measure.

The main demographic data collected showed that $69.7 \%$ of respondents belong to females, and $30.3 \%$ are males. Regarding the year of graduation, the results indicated that $41.4 \%$ graduated before 2019, 26.9\% graduated in 2020, 23.4\% in 2019 and $8.3 \%$ in 2021. This may determine that the largest share of respondents have been active in the labor market for a long time, which can be demonstrated through the answers referring to their seniority, so $33.8 \%$ are over 3 years old, the rest being in seniority between 6 months and 3 years. Fortunately, we can say based on the answers collected that $60 \%$ of respondents work in the field of undergraduate studies, $40 \%$ working in different fields of activity.

The next two sections contain elements related to research variables that have been statistically interpreted using the IBM SPSS program. 


\section{RESULTS AND DISCUSSIONS}

For a conclusive statistical analysis, the Cronbach Alpha coefficient was calculated for each group of variables in order to evaluate the internal consistency of the scales. To be accepted, the value of the Cronbach Alpha coefficient must exceed the generally accepted threshold of 0.7 (Opariuc-Dan, 2011; Popa \& Ștefan, 2019), in this case they validate the variables proposed for analysis by multiple linear regression. For testing the research hypotheses, four variables were considered: employment rate, specialized knowledge, migration, job satisfaction whose items are presented together with their descriptive statistics and the Cronbach Alpha coefficient in Table 1.

Table 1. Descriptive statistics and Cronbach's Alpha

\begin{tabular}{|c|c|c|c|}
\hline & Mean & $S D$ & $\begin{array}{c}\text { Cronbach } \\
\text { ALPHA }\end{array}$ \\
\hline \multicolumn{4}{|c|}{ Employment rate } \\
\hline Frequency of job application & 2.880 & 1.500 & \multirow{6}{*}{0.701} \\
\hline Frequency of participation to interviews & 2.480 & 1.260 & \\
\hline Required Experience & 3.490 & 1.500 & \\
\hline Required higher education & 3.530 & 1.320 & \\
\hline Marks gained during higher education & 2.010 & 1.310 & \\
\hline The prestige of the university & 2.420 & 1.432 & \\
\hline \multicolumn{4}{|c|}{ Specialized knowledge } \\
\hline General knowledge & 3.810 & 1.192 & \multirow{6}{*}{0.873} \\
\hline IT/Office & 2.710 & 1.285 & \\
\hline Teamwork & 3.460 & 1.155 & \\
\hline Capacity for analysis and synthesis & 3.740 & 1.093 & \\
\hline Critical thinking & 3.610 & 1.180 & \\
\hline Ability to expose knowledge in practice & 3.340 & 1.260 & \\
\hline \multicolumn{4}{|c|}{ Migration } \\
\hline Internal migration during studies & 2.680 & 1.650 & \multirow{4}{*}{0.827} \\
\hline External migration during studies & 1.970 & 1.350 & \\
\hline Internal migration after graduation & 3.230 & 1.720 & \\
\hline External migration after graduation & 2.320 & 1.540 & \\
\hline
\end{tabular}

Job satisfaction

\begin{tabular}{|l|c|c|}
\hline Salary & 3.150 & 1.023 \\
\hline Salary benefits & 3.000 & 1.149 \\
\hline Paid overtime & 2.810 & 1.298 \\
\hline Work schedule & 3.470 & 1.191 \\
\hline Out of office days & 4.020 & 1.115 \\
\hline Work Conditions & 3.760 & 1.132 \\
\hline Job security & 4.010 & 0.993 \\
\hline Appreciation at work & 3.520 & 1.281 \\
\hline Friendship with co-workers & 3.70 & 1.132 \\
\hline Attitude and behavior of superiors & 3.69 & 1.205 \\
\hline Chances of promotion & 3.41 & 1.267 \\
\hline Professional development & 3.65 & 1.239 \\
\hline Using skills & 3.74 & 1.177 \\
\hline Productivity & 3.88 & 1.02 \\
\cline { 1 - 2 }
\end{tabular}

Source: Data processing by authors with IBM SPSS 
Given the results obtained in Table 1, based on the identified variables, the proposed statistical hypotheses were tested using linear regression analysis.

The first hypothesis of the study refers to the determination of the influence of specialized knowledge on the employment rate of graduates, the results of which are presented in table 2.

Table 2. The influence of specialized knowledge on the employment rate

\begin{tabular}{|c|c|c|c|c|c|c|c|c|}
\hline \multirow{3}{*}{ Variables } & \multicolumn{8}{|c|}{ Employment rate } \\
\hline & \multirow{2}{*}{ B } & \multirow{2}{*}{$\boldsymbol{\beta}$} & \multirow{2}{*}{$\mathbf{t}$} & \multirow{2}{*}{$\mathbf{p}$} & \multicolumn{2}{|c|}{$95 \% \mathrm{CI}$} & \multicolumn{2}{|c|}{ Collinearity } \\
\hline & & & & & Lower & Upper & Tolerance & VIF \\
\hline Constant & 1.658 & & 7.165 & 0.000 & 1.200 & 2.115 & & \\
\hline $\begin{array}{l}\text { Specialized } \\
\text { knowledge }\end{array}$ & 0.332 & 0.394 & 5.119 & 0.000 & 0.204 & 0.460 & 1.000 & 1.000 \\
\hline R Square & \multicolumn{8}{|c|}{0.394} \\
\hline F/ Sig. F & \multicolumn{8}{|c|}{$26.200 / 0.000$} \\
\hline
\end{tabular}

Source: Data processing by authors with IBM SPSS

The proposed simple regression model is valid because the probability of the $\mathrm{F}$ test is less than 0.05 $F=26.200, p<0.001)$. Thus, according to the determination coefficient $\left(R^{2}=0.394\right)$, it can be stated that $39.4 \%$ of the employment rate variance can be explained by the level of knowledge acquired during the specialized studies. The regression coefficient for the specialized knowledge is significantly different from 0 , the significance level of the statistical test being less than 0.05 , having a positive influence on the employment rate $(\beta=0.394, t=$ $5.119,95 \% C I[0.204,0.460])$. Thus, for each increase by one unit of specialized knowledge, the employment rate will increase by approximately 0.204-0.460 units.

These results validate the idea that people who choose to pursue a study program in university education have more chances of employment, given the increased competitiveness in the labor market. Also, the skilled labor force in a country contributes to the decrease of the unemployment rate but also to the increase of the economic prosperity.

In recent years, the role of higher education has increased significantly in the development of national economies, due to the expansion of the knowledge economy, which creates and transforms knowledge into innovation. The knowledge economy should be understood as an influential economy in which most of the GDP of a given country (Matiuk \& Bassarabova, 2021).

The second hypothesis of our study regarding the determination of the influence of expertise on job satisfaction is presented in Table 3 .

Table 3. The influence of specialized knowledge on job satisfaction

\begin{tabular}{|c|c|c|c|c|c|c|c|c|}
\hline \multirow{2}{*}{ Variables } & \multicolumn{8}{|c|}{ Job Satisfactions } \\
\cline { 2 - 8 } & \multirow{2}{*}{$\boldsymbol{B}$} & $\boldsymbol{\beta}$ & $\boldsymbol{t}$ & $\boldsymbol{p}$ & \multicolumn{2}{|c|}{$\mathbf{9 5 \%}$ CI } & \multicolumn{2}{c|}{ Collinearity } \\
\cline { 5 - 9 } & & & & Lower & Upper & Tolerance & VIF \\
\hline Constant & 2.263 & & 9.158 & 0.000 & 1.775 & 2.751 & & \\
\hline $\begin{array}{c}\text { Specialized } \\
\text { knowledge }\end{array}$ & 0.376 & 0.413 & 5.428 & 0.000 & 0.239 & 0.513 & 1.000 & 1.000 \\
\hline R Square & \multicolumn{8}{|c|}{0.413} \\
\hline F / Sig. F & \multicolumn{8}{|c|}{$29.460 / 0.000$} \\
\hline
\end{tabular}

Note: $95 \% \mathrm{CI}-95 \%$ confidence interval. VIF = variance inflation factor.

Source: Data processing by authors with IBM SPSS

This proposed regression model is validated, as the $\mathrm{F}$ test is significant $F=29.460, p<0.001)$. Therefore, it can be stated that the value of the determination coefficient $\left(R^{2}=0.413\right)$ shows that 
the variance in job satisfaction can be explained by the level of knowledge acquired during the specialized studies. The regression coefficient for expertise has a positive influence on job satisfaction, as it is significantly different from 0 , as the value of the coefficient $p$ is less than the maximum accepted value $0.05(\beta=0.413, t=5.428,95 \% C I[0.239,0.513]$. Thus, for each oneunit increase in specialized knowledge, job satisfaction will increase by approximately $0.239-0.513$ units. The results show that a high level of knowledge acquired during specialized studies (specialized knowledge, IT, teamwork, ability to analyze and synthesize, critical thinking) contributes to increasing the satisfaction felt by employees at work.

Next, we propose a multiple regression model, Table 4, to determine the influence of internal and external migration on job satisfaction.

Table 4. The influence of internal and external migration on job satisfaction

\begin{tabular}{|c|c|c|c|c|c|c|c|c|}
\hline \multirow{2}{*}{ Variables } & \multicolumn{8}{|c|}{ Job Satisfaction } \\
\cline { 2 - 9 } & $\mathbf{B}$ & $\boldsymbol{\beta}$ & $\mathbf{t}$ & $\mathbf{p}$ & \multicolumn{2}{|c|}{$\mathbf{9 5 \%}$ CI } & \multicolumn{2}{c|}{ Collinearity } \\
\cline { 2 - 9 } & & & & Lower & Upper & Tolerance & VIF \\
\hline Constant & 3.183 & & 20.334 & 0.000 & 2.873 & 3.492 & & \\
\hline $\begin{array}{c}\text { Internal } \\
\text { Migration }\end{array}$ & 0.120 & 0.218 & 2.267 & 0.025 & 0.015 & 0.224 & 0.721 & 1.387 \\
\hline $\begin{array}{c}\text { External } \\
\text { Migration }\end{array}$ & 0.010 & 0.016 & 0.164 & 0.870 & -0.109 & 0.129 & 0.721 & 1.387 \\
\hline R Square & \multicolumn{70}{|c|}{0.051} \\
\hline F/ Sig. F & \multicolumn{70}{|c|}{$3.854 / 0.023$} \\
\hline
\end{tabular}

Note: $95 \% \mathrm{CI}-95 \%$ confidence interval. VIF = variance inflation factor.

Source: Data processing by authors with IBM SPSS

The results indicate that the two independent variables explain $5.1 \%$ of the variation in job satisfaction $\left(R^{2}=0.051\right)$. Of these, internal migration brings the largest single contribution $(\beta=$ $0.218, t=2.267,95 \% C I[0.015,0.224]$, the value of the $\mathrm{p}$ coefficient being lower than the maximum accepted value 0.05 . We can observe that the independent variable external migration does not have a statistically significant influence $(\beta=0.016, t=0.164,95 \% C I[-0.109,0.129]$, since the value of the p-coefficient is higher than the maximum accepted value 0.05 . Thus, we can deduce that for the respondents of our questionnaire, external migration is not a criterion of job satisfaction. Instead, internal migration, from small towns to more developed cities in Romania, means diversifying employment opportunities, respectively increasing job satisfaction. Thus, for each oneunit increase in internal migration, job satisfaction will increase by about $0.015-0.224$ units.

Considering the results of the regression analysis, the model shows that internal and external migration describes the changes that occur for job satisfaction, since that the results of the $\mathrm{F}$ test are statistically significant $F=3.854, p<0.05$ ).

To validate the third hypothesis, we analyzed from a statistical point of view the persons who are employed in the field of specialized studies, the characteristics of the answers being concretized in table 5. Thus, 87 of the respondents stated that they work in the field of specialized studies, while 58 respondents work in other fields of activity.

Table 5. Descriptive statistics of the respondents employed in the fields of specialized studies

\begin{tabular}{|c|c|c|c|c|c|}
\hline & & N & Mean & Std. Deviation & Std. Error Mean \\
\hline $\begin{array}{c}\text { Employees in the specialized } \\
\text { studies field }\end{array}$ & YES & 87 & 3.793 & 0.751 & 0.081 \\
\cline { 2 - 6 } & NO & 58 & 3.204 & 0.875 & 0.115 \\
\hline
\end{tabular}

Note: N - number of cases. Source: Data processing by authors with IBM SPSS 
Further, we used the independent samples t-test to identify whether there are statistically significant differences between the satisfaction of employees in the field of specialized studies and the satisfaction of people employed in a field other than completed studies, the results being presented in Table 6.

Table 6. Significant differences between the satisfaction of persons employed in the field of specialized studies and the satisfaction of persons employed in a different field.

\begin{tabular}{|l|c|c|c|c|c|c|}
\hline \multirow{2}{*}{ Job Satisfaction } & \multirow{F}{*}{$\boldsymbol{F}$} & Sig.F & $\boldsymbol{t}$ & $\boldsymbol{p}$ & \multicolumn{2}{|c|}{ CI 95\% } \\
\cline { 1 - 4 } & & & Lower & Upper \\
\hline $\begin{array}{l}\text { Equal variances } \\
\text { assumed }\end{array}$ & 0.673 & 0.414 & 4.325 & 0.000 & 0.320 & 0.858 \\
\hline $\begin{array}{l}\text { Equal variances not } \\
\text { assumed }\end{array}$ & & & 4.195 & 0.000 & 0.311 & 0.867 \\
\hline
\end{tabular}

Source: Data processing by authors with IBM SPSS

Regarding the verification of the presumption of equality of variances, test $\mathrm{F}$ does not have a significant value ( $p>0.05)$, so the results from the first row of table 6 , respectively equal variances assumed, will be interpreted. Therefore, it can be seen that the statistical $\mathrm{T}$ test used has a statistically significant value $(\mathrm{p}<0.05)$, which means that there are significant differences between the satisfaction of people employed in the field of specialized studies $(M=3.793, S D=$ 0.751 ) and the satisfaction of people employed in a field different from the completed studies $M=$ $3.204, S D=0.875, t=4.325, p<0.001$ ).

In terms of results, we can say that people who work in the field of graduate studies are more likely to develop professionally in the organization, which means an increase in job satisfaction.

According to Maslow's theory (Lefter, et al., 2008), individuals who tend to meet the needs at the top of the pyramid regarding self-knowledge, achievement and personal development have greater satisfaction in professional life.

\section{CONCLUSION}

Considering the aim pursued in this research, represented by determining the influence between the knowledge acquired after studying a specialized field and the employment rate, as well as their influence on job satisfaction, three hypotheses were tested that demonstrated the concepts mentioned with using regression analysis and t test for independent samples. Following the results obtained, the conclusions of the research were drawn.

The educational choice regarding the university education (the type of graduated studies, the field of studies, etc.) represented a landmark in this paper, being an important coordinate according to which a person guides his career. The education system affected by the changes it has undergone recently has led to a rethinking of the entire process of insertion on the labor market and the adaptation to the new environment of all stakeholders involved. In order to identify the consequences of educational choice on a person's career, variables such as acquired knowledge, employment rate, job satisfaction, internal and external migration were considered.

In the context of determining the influence of acquired knowledge on employment rate and job satisfaction, we observed that there are positive influences of the independent variable in both cases, and people who choose to pursue a degree in university education have more chances of employment, in conditions for increasing competitiveness in the labor market. Also, the obtained results show that a high level of knowledge acquired during the specialized studies (specialized knowledge, IT, teamwork, capacity of analysis and synthesis, critical thinking) contributes to the increase of the satisfaction, felt by the employees at work. 
The results of the multiple linear regression analysis performed to identify the influences of internal and external migration on job satisfaction are validated only in the case of internal migration. Thus, we found that internal migration from small towns to more developed cities in Romania involves diversifying employment and professional development opportunities, which leads to increased job satisfaction, while external migration does not influence job satisfaction. which can be attributed to the fact that people who emigrate in search of a job, find it difficult to find a job in the field of graduate studies.

At the same time, by comparing the satisfaction of persons employed in the field of specialized studies and the satisfaction of persons employed in a field different from that of completed studies we concluded that they have a different level of satisfaction in the sense that people working in the field of specialized studies. they are more likely to develop professionally within the organization, which means an increase in job satisfaction.

Therefore, this study shows that there are positive influences of the knowledge acquired after completing a higher education program on the employment rate of graduates and their job satisfaction. This conclusion is confirmed by the fact that $60 \%$ of the respondents work in the field of undergraduate studies, $40 \%$ working in different fields of activity.

The results of the research can have several implications for society. This study can be useful for job seekers because knowing that a job in the field of specialized studies contributes to increasing job satisfaction would be oriented towards that field. It could also be useful for employers, as they know what underpins the satisfaction of their employees and could provide them with professional development opportunities in that direction.

Regarding the limits of the research, they consisted in the difficulty of obtaining a necessary number of answers so that the sample is representative and the results can be extended to the whole population. Thus, out of the total number of people active on the labor market, only those who have completed their undergraduate studies and want to participate in research have been chosen. Regarding the future research directions, we propose to consider an analysis of job satisfaction and employment rate according to age, seniority in the organization, gender of respondents and even their level of education.

\section{REFERENCES}

Boddy, C. R. (2016). Sample size for qualitative research. Qualitative Market Research: An International Journal, 19(4), 426-432. DOI:10.1108/QMR-06-2016-0053.

Commission/EACEA/Eurydice, E. (2020). The European Higher Education Area in 2020: Bologna Process Implementation Report. Luxembourg: Publications Office of the European Union. Available at: https://eacea.ec.europa.eu/national-policies/eurydice/content/european-highereducation-area-2020-bologna-process-implementation-report_en, Accessed 20 August 2021.

Chellia, H. (2018). A Brief Overview on Students' Mobility and its Impact on Second Language Use. International Journal of Emerging Trends in Social Sciences, 2(2), 64-73, DOI:10.20448/2001.22.64.73.

Dell, R. B., Holleran, S., \& Ramakrishnan, R. (2002). Sample size determination. ILAR journal, 43(4), 207-213. DOI:10.1093/ilar.43.4.207.

Desselle, S. P., Raja, L., Andrews, B., \& Lui, J. (2018). Perceptions of organizational culture and organizational citizenship by faculty in U.S. colleges and schools of pharmacy. Currents in Pharmacy Teaching and Learning, 10(4), 403-412. DOI: 10.1016/j.cptl.2017.12.017.

Drewery, D., \& Pretti, J. (2021) The building blocks of relevant work experiences. International Journal of Work-Integrated Learning, 22(2), 241-251.

Education, Audiovisual and Culture Executive Agency, (2010). The European Higher Education Area in 2020, Brussels. Available at: https://eacea.ec.europa.eu/nationalpolicies/eurydice/sites/default/files/ehea_bologna_2020.pdf, Accessed 20 August 2021. 
European-Commission (2020). Education and Training. Available at: https://ec.europa.eu /education/policies/european-policy-cooperation/european-semester-country-analysis_ro, Accessed 20 August 2021.

Eurostat (2021a). Education and training statistics at regional level. Available at: https://ec.europa.eu/eurostat/statisticsxplained/index.php?title=Education_and_training_statist ics_at_regional_level\#Transition_from_education_to_work, Accessed 24 August 2021.

Eurostat (2021b). Employment and activity by sex and age (1992-2020) - annual-data. Available at: https://ec.europa.eu/eurostat/databrowser/view/lfsi_emp_a_h/default/table? Lang = en, Accessed 24 August 2021.

Eurostat (2021c). Methods to find current job by migration status, educational attainment level and type of contract. Available at: https://ec.europa.eu/eurostat/databrowser/view/lfso_ 14leecm/default/table? Lang = e. n., Accessed 24 August 2021.

Eyupoglu, S. Z., \& Saner, T., (2009). The relationship between job satisfaction and academic rank: a study of academicians in Northern Cyprus. Current Research in Behavioral Sciences, 1(1), 686-691. DOI: 10.1016/j.sbspro.2009.01.120.

Krejcie, R. V., \& Morgan, D. W. (1970). Determining sample size for research activities. Educational and psychological measurement, 30(3), 607-610.

Lefter, V., Deaconu, A., Marin, I, \& Elvira Nica, C.-V. M., (2008). Managementul resurselor umane. Teorie și practică. Ediția a II-a. Bucuresti: Editura Economică.

Svabova L, Durica M, Kramarova K, Valaskova K, \& Janoskova K. (2019). Employability and Sustainability of Young Graduates in the Slovak Labour Market: Counterfactual Approach. Sustainability. 11(16), 4462. DOI:10.3390/su11164462.

Matiuk, T., \& Bessarabova, N. K. (2020). Correlation between level of education and employment rate. Economics Finances Law, 5(3), 24-27. DOI:10.37634/efp.2020.5(3).6.

Opariuc-Dan, C. (2011). Statistică aplicată în științele socio-umane. Analiza asocierilor și a diferențelor statistice. Cluj: Editura ASCR.

Padmanabhan, S. (2021). The impact of locus of control on workplace stress and job satisfaction: A. Current Research in Behavioral Sciences, 2, 100026. DOI: 10.1016/j.crbeha.2021.100026.

Popa, I., \& Ștefan, S. (2019). Modeling the Pathways of Knowledge Management Towards Social and Economic Outcomes of Health Organizations. International Journal of Environmental Research and Public Health, 16(7), 1114. DOI:10.3390/ijerph16071114.

Robotă, M. R. (2018). Personalitate, motivație și performanță academică. Iași: Institutul European.

Şerban, A. C. (2010). Implicaţii ale nivelului de educaţie. Economie teoretică şi aplicată, XIX (3 (568)), 125-135. 